\title{
Australian Journal of \\ Growth and yield traits of pickling cucumber plants to measure the impact of different irrigation management practices
}

\author{
Fernando Soares de Cantuário ${ }^{1}$, Leandro Caixeta Salomão ${ }^{1}$, Carmen Rosa da Silva Curvêlo ${ }^{1}$, João de Jesus \\ Guimarães ${ }^{2}$, José Magno Queiroz Luz ${ }^{3}$, Luiz Leonardo Ferreira ${ }^{4}$, Alexandre Igor Azevedo Pereira ${ }^{1 *}$ \\ ${ }^{1}$ Horta Field Lab, Instituto Federal Goiano, Campus Urutaí, GO, Brasil \\ ${ }^{2}$ Departamento de Engenharia Agrícola, Faculdade de Ciências Agronômicas, Universidade Estadual Paulista, SP, \\ Brasil \\ ${ }^{3}$ Instituto de Ciências Agrárias, Universidade Federal de Uberlândia, Uberlândia, MG, Brasil \\ ${ }^{4}$ Departamento de Agronomia, UNIFIMES, Mineiros, GO, Brasil
}

\begin{abstract}
Cucumber (Cucumis sativus L) is mostly cultivated by family-based farmers worldwide and processed to pickles by small to midsized industries generating employment and income. But irrigation management needs better investigation for adapting adequate sustainable practices. The rational use of irrigation water still has been neglected nowadays, but can improve cucumber production. The objective was to evaluate different irrigation levels on growth and yield parameters of the Amour $F_{1}$ cucumber hybrid through time under greenhouse. Treatments consisted of five irrigation levels (amounts of water applied of 62, 93, 124, 155 and $186 \mathrm{~mm}$ ), ranging from water stress to excess water. The experimental design was randomized blocks, with four replications. Vegetative growth and yield showed different responses to the irrigation levels. Plant height and internode length were less influenced by the irrigation levels, throughout the time, than stem diameter and root length. Cucumber yield was low with $62 \mathrm{~mm}$ and $93 \mathrm{~mm}$, higher with $124 \mathrm{~mm}$ irrigation, and delayed in time at $155 \mathrm{~mm}$ and $186 \mathrm{~mm}$. Water excess (186 mm) was not beneficial for pickling cucumber plants, and the amount of $124 \mathrm{~mm}$ was satisfactory for their development and yield. The results of this study may allow adoption of sustainable irrigation practices with no waste of agricultural water, a scarce resource worldwide.
\end{abstract}

Keywords: Cucurbitaceae, Greenhouse, Water, Water Excess, Water Deficit.

\section{Introduction}

Pickling cucumber, Cucumis sativus L. (Cucurbitaceae), processed and marketed by industries, generates employment and income worldwide, including, in developing countries. Industries established in the south of Brazil aimed to adapt their pickling cucumber production system in more central areas of the country, where the Brazilian Savanna biome (Cerrado type) predominates. Purchase and sale contracts prior to planting with small and medium sized farmers guarantee commercialization and processing. The edaphoclimatic characteristics of the Cerrado are favorable for plant development, such as soybean, bean, cotton, tomato, potato, onion and garlic because, among other factors, the abundance of water for irrigation (Klink et al. 2005).

Technologies as greenhouses, drip irrigation, fertirrigation, grafts and mulching (Yaghi et al. 2013) allow high cucumber yields and fruit quality. Drip irrigation is been gradually adopted by vegetable crop producers in Goiás state, Brazil. Limited technical-scientific information, regarding irrigation management in cucumber plants reduces their full genetic potential in central areas of Brazil. In some cases, the lack of knowledge about irrigation management prevents farmers to supply sufficient cucumber fruits to industries.
Cucumber plants, as other vegetables, do not tolerate water stress or excess, because approximately $85 \%$ of its root zone is up to $30 \mathrm{~cm}$ below the soil surface (Randall and Locascio, 1988). Negative effects of water shortage or excess were reported for Cucumis species (Oliveira et al. 2011). Irrigation systems should provide enough water in the root zone while avoiding nutrient leaching to deeper soil layers (Blanco and Folegatti, 2001). This problem occurs in greenhouses due to soil salinization by excessive fertilizers and water use for cucumber growth, development and yield (Blanco et al., 2002).

Development of cucumber plant through the time (agedependent analysis) must be investigated to know fertilizer use, cultural practices and harvesting (Espínola et al., 2001). Plant responses to different irrigation levels can also be incorporated to an age-dependent analysis perspective. The pickling cucumber plant has relatively short cycle and requires continued visual monitoring to adopt cultural practices, reflecting high yields. The monitoring of plant height, stem diameter and internodes length may indicate the correct management of cucumber plants with direct relationship with yield (Kahlen and Chen 2015). We investigated growth and yield parameters of pickling 
cucumber plants (Amour $F_{1}$ hybrid) subjected to different irrigation water levels through the time, and.

\section{Results and Discussion}

\section{Greenhouse climatic conditions}

The temperature (mean $28.25 \circ \mathrm{C}$ ) and relative humidity (mean 57\%) were measured during our experimental procedures (Fig. 1), confirming the satisfactory climatic conditions for the cucumber growth, because no symptoms of temperature-dependent disorders were observed. Cucumber plants under unfavorable abiotic conditions, such as temperature and relative humidity, may encounter reduced number of female flowers, delay in fruit growth and symptoms of leaf mineral disorders (Yaghi et al., 2013). A better control of climatic variables in greenhouse can explain the fact that most pickling cucumber parthenocarpic hybrids (such as Amour F1 hybrid) are suggested to explored under protected cultivation. Once abiotic factors are adverse, the genetic potential of a given cucumber cultivar may be underexploited leading to a reduced plant yield by up to $46.3 \%$ (Reis et al., 1991).

\section{Cucumber plant height}

Cucumber plant height was similar among different irrigation levels at eight $(F=2.92, P=0.06)$ and 15 DAT ( $F=$ 2.61, $P=0.07$ ) but differed along the other time intervals (Fig. 2a). Higher plants were observed from $22^{\text {th }}$ DAT until the last evaluation (64 DAT) with $155 \mathrm{~mm}$ level irrigation (Fig. 3a), but lower with $62 \mathrm{~mm}$ at the same time interval. In this case, linear regression models were the best fitted that helped observations of the plant height behavior according to the time intervals and treatments (Fig. 3a). Plant height regression equations and coefficients were $62 \mathrm{~mm}(\mathrm{y}=-0.39$ $+0.55 x$ and $\left.R^{2}=0.99\right), 93 \mathrm{~mm}\left(y=-0.49+0.60 x\right.$ and $\left.R^{2}=0.99\right)$, $124 \mathrm{~mm}\left(\mathrm{y}=-0.48+0.60 \mathrm{x}\right.$ and $\left.\mathrm{R}^{2}=0.98\right), 155 \mathrm{~mm}(\mathrm{y}=-0.52+$ $0.64 x$ and $\left.R^{2}=0.99\right)$ and $186 \mathrm{~mm}\left(y=-0.40+0.57 x\right.$ and $R^{2}=$ 0.98).

The linear growth in height of cucumber plants over the time interval (Fig 2a) was similar to that observed for the cucumber cv. Hokushin, grafted on Curcubita spp., Excite-lkki hybrid under different salinity and irrigation levels (Blanco et al., 2002). The maintenance of an irrigation depth up to 20 DAT can explain the lack of treatment effect in both eight and 15 DAT time intervals. However, irrigation level effects appeared from 22 DAT can confirm the great sensitivity of this plant to water deficit. Low water levels $(62 \mathrm{~mm}$ ) may have impaired cell division processes, responsible for plant growth (Anjun et al. 2011). Increasing differences with plant age can be explained because the different irrigation levels were applied continuously during the cucumber plants lifecycle.

\section{Cucumber stem diameter}

Stem diameter values were almost identical in more than half of the whole-time interval evaluated, regardless of the irrigation levels (Fig. 2b). The effect of the irrigation levels was observed at $15(\mathrm{~F}=3.10, P=0.04), 22(\mathrm{~F}=5.97, P=0.00)$, $29(\mathrm{~F}=3.74, P=0.02), 57(\mathrm{~F}=16.19, P=0.00)$ and 64 DAT $(\mathrm{F}=$
25.07, $P=0.00$ ) (Fig. 2b). Cubic polynomial regression models had the best fit to observe cucumber stem diameter behavior (Fig. 3b). Stem diameter was increased at $155 \mathrm{~mm}$ until the $22^{\text {th }}$ DAT with stabilization between the $29^{\text {th }}$ and $50^{\text {th }}$ DAT. A new stem diameter growth from $57^{\text {th }}$ to $64^{\text {th }}$ DAT was observed (Fig. 3b). A stabilization was occurred between the time intervals of 29 and 50 DAT. Stem diameter growth performance was clearly less evident in the other irrigation levels evaluated. The final growth trend of stem diameter was lower with $125 \mathrm{~mm}$ irrigation level between the 57 and 64 DAT time interval (Fig. 3b). Stem diameter regression equations and coefficients were $62 \mathrm{~mm}(\mathrm{y}=-0.58+0.95 \mathrm{x}-$ $0.19 x^{2}+0.14 x^{3}$ and $\left.R^{2}=0.90\right), 93 \mathrm{~mm}(y=-0.44+0.69 x-$ $0.11 x^{2}+0.67 x^{3}$ and $\left.R^{2}=0.90\right), 124 m m(y=-0.49+0.83 x-$ $0.17 x^{2}+0.14 x^{3}$ and $\left.R^{2}=0.89\right), 155 \mathrm{~mm}(y=-0.99+0.16 x-$ $0.44 x^{2}+0.39 x^{3}$ and $\left.R^{2}=0.91\right)$ and $186 m m(y=-0.79+0.12 x-$ $0.30 x^{2}+0.24 x^{3}$ and $\left.R^{2}=0.88\right)$.

Differences in the stem diameter observed near 46 DAT were also reported for the Japanese cucumber with soilwater tensions of 15,30, 60 and $120 \mathrm{kPa}$ (Oliveira et al. 2011). Many physiological changes occur according to the phenological cycle of the cucumber plant (Espínola et al., 2001) that may have influenced the polynomial curve behavior observed for the stem diameter as function of the irrigation levels. Cucumber plants tend to concentrate energy to build fruits, which reduces stem diameter expansion. The new stem diameter expansion are usually experienced near the final life-cycle, once the expense for fruit production is no longer relevant (Canizares and Goto 2002). The plasticity of stem diameter expansion in cucumber plants can be strongly influenced by management variables (Jaffar and Wahid 2014) and environmental effects, such as water stress.

\section{Cucumber internode length}

Internode length of cucumber plants at $8(F=1.55, P=0.23)$ and $15(F=0.73, P>0.05)$ DAT was similar comparing all irrigation levels, but differed between treatments at the other time intervals (Fig. 2c). Cubic polynomial regression models showed the best fit to explain internode variation length, with a lower stabilization trend over the whole evaluation period. Lower values were observed at $186 \mathrm{~mm}$ irrigation levels (between 22 and 29 DAT) and at $125 \mathrm{~mm}$ (between 43 DAT and 50 DAT) (Fig. 3c). The plant internode length was shorter at the end of the evaluation period (64 DAT) when cucumber plants were submitted to the $124 \mathrm{~mm}$ irrigation level (Fig. 3c). Internode length regression equations and coefficients were $62 \mathrm{~mm}(\mathrm{y}=0.35+0.34 \mathrm{x}-$ $0.56 x^{2}+0.33 x^{3}$ and $\left.R^{2}=0.96\right), 93 \mathrm{~mm}(y=0.22+0.35 x-$ $0.60 x^{2}+0.37 x^{3}$ and $\left.R^{2}=0.97\right), 124 \mathrm{~mm}(y=0.29+0.32 x-$ $0.46 x^{2}+0.23 x^{3}$ and $\left.R^{2}=0.96\right), 155 m m(y=-0.82+0.40 x-$ $0.79 x^{2}+0.56 x^{3}$ and $\left.R^{2}=0.96\right)$ and $186 \mathrm{~mm}(\mathrm{y}=0.44+0.37 \mathrm{x}-$ $0.73 x^{2}+0.52 x^{3}$ and $\left.R^{2}=0.96\right)$.

Differences in the internode length as a function of treatments may be a consequence of plant height responses and not necessarily the effect of the irrigation levels as observed in tomato plants (Sibomana et al. 2013). Positive and significant correlations $\left(R^{2}=0.576\right)$ between internode length and plant height of cucumber plants were also reported (Ando and Grumet, 2006). This reinforces the hypothesis that the internode length variation in cucumber 

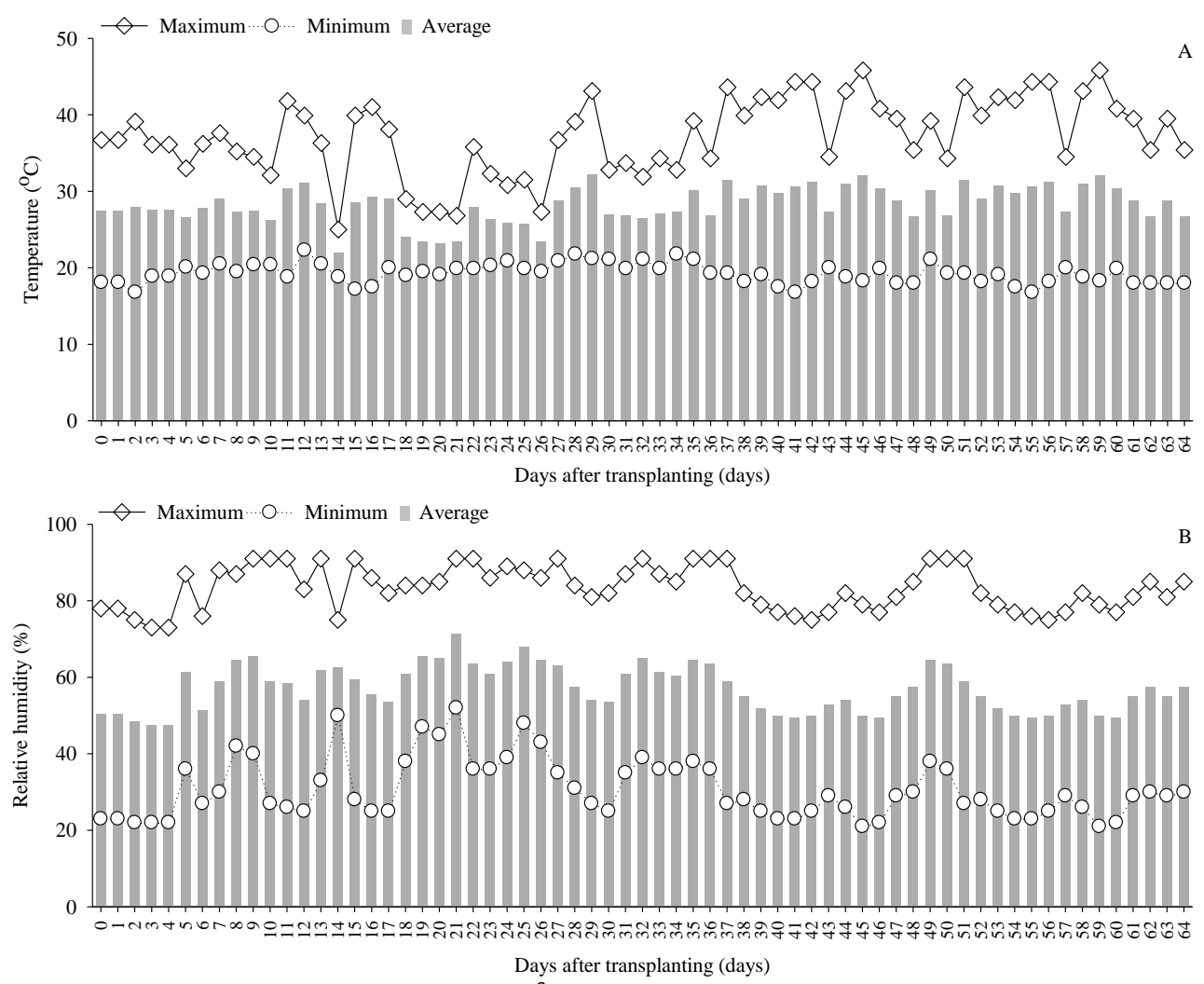

Fig. 1 Maximum, mean and minimum values of temperature $\left({ }^{\circ} \mathrm{C}\right)$ (Fig. 1a) and relative humidity (\%) (Fig. 1b) quantified during the experimental period under greenhouse condition.

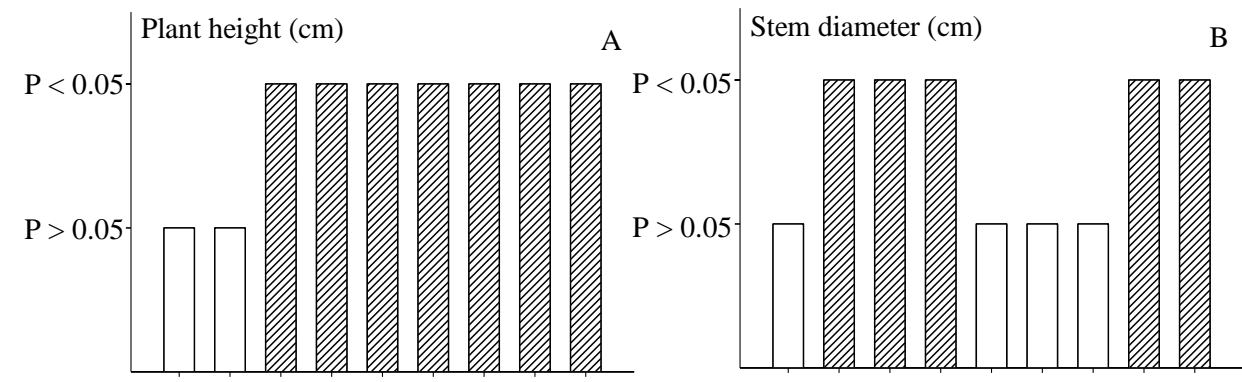

$\begin{array}{lllllllll}8 & 15 & 22 & 29 & 36 & 43 & 50 & 57 & 64\end{array}$

$\begin{array}{lllllllll}8 & 15 & 22 & 29 & 36 & 43 & 50 & 57 & 64\end{array}$

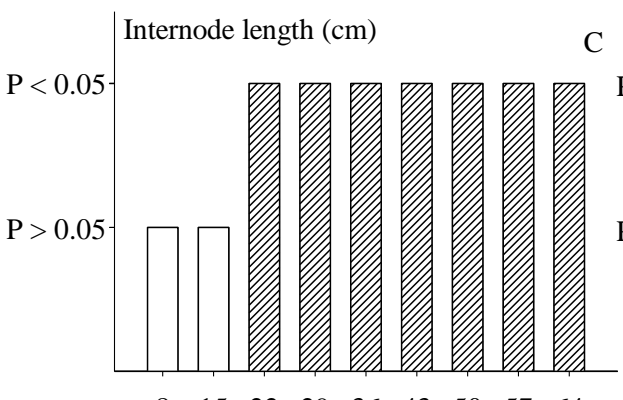

Root lenght $(\mathrm{cm})$

$\mathrm{D}$

$\begin{array}{llllllllll}8 & 15 & 22 & 29 & 36 & 43 & 50 & 57 & 64\end{array}$

Days after transplanting (DAT)

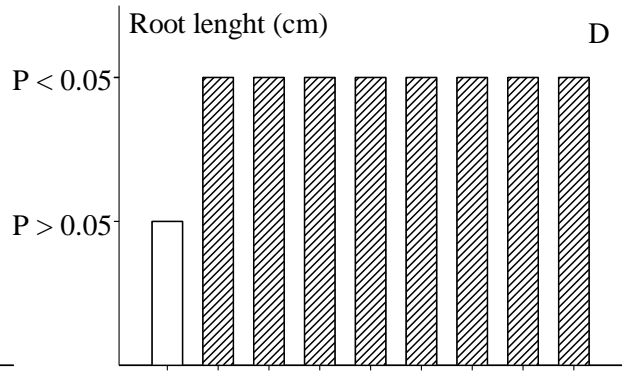

$\begin{array}{lllllllll}8 & 15 & 22 & 29 & 36 & 43 & 50 & 57 & 64\end{array}$

Days after transplanting (DAT)

Fig 2. Graphical representation of the ANOVA for the dependent variables plant height $(\mathrm{cm})(\mathrm{a})$, stem diameter (cm) (b), internode length $(\mathrm{cm})(\mathrm{c})$ and root length $(\mathrm{cm})(\mathrm{d})$ of Amour F1 pickling cucumber hybrid (Cucumis sativus L.) (Cucurbitaceae) plants submitted to irrigation levels $(62,93,124,155$ and $186 \mathrm{~mm}$ ) along different days after transplanting. $P<0.05$ (significant at $5 \%$ probability level by $\mathrm{F}$ test and with bars filled with cross lines) and $P>0.05$ (not significant at $5 \%$ probability level by F-test and with bars filled in white). 

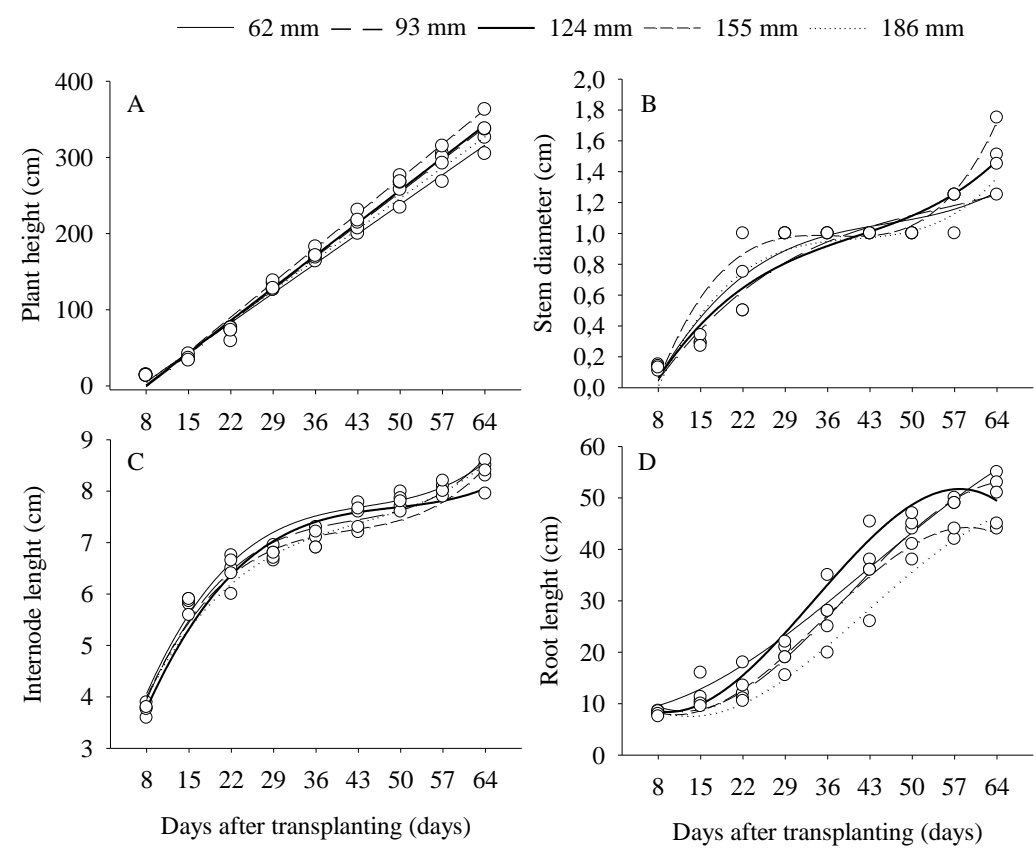

Fig 3. Regression analysis for plant height (a), stem diameter (b), internode length (c) and root length (d) of the Amour F1 pickling cucumber hybrid (Cucumis sativus L.) (Cucurbitaceae) according to the age-class (days after transplanting) and submitted to irrigation levels $(62,93,124,155$ and $186 \mathrm{~mm})$.
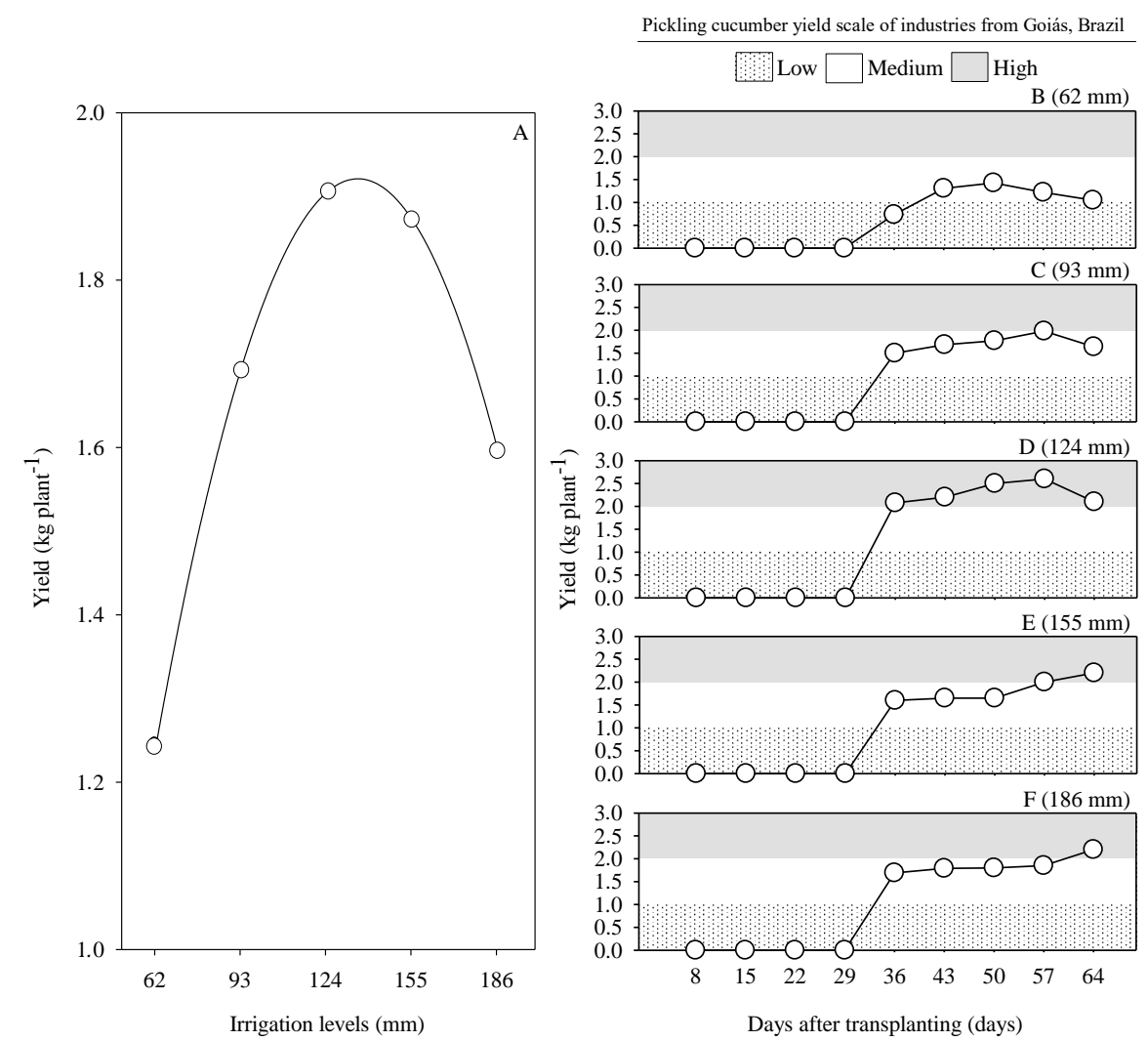

Fig 4. Amour F1 pickling cucumber hybrid (Cucumis sativus L.) (Cucurbitaceae) yield (kg plant ${ }^{-1}$ ) (Mean) regression analysis (a) and according to the days after transplanting at $62 \mathrm{~mm}$ (b), $93 \mathrm{~mm}$ (c), $124 \mathrm{~mm}$ (d), $155 \mathrm{~mm}$ (e) and $186 \mathrm{~mm}$ (f). Yield values were established according to the industry standards as low yield: $<1 \mathrm{~kg} \mathrm{plant}^{-1}$, medium yield: $>1$ to $2 \mathrm{~kg} \mathrm{plant}^{-1}$ and high yield: $>2 \mathrm{~kg}$ plant $^{-1}$.

plants tends to be induced by inadequate lighting conditions (Kahlen and Chen, 2015). Longer internodes benefit light distribution in adult plants; therefore, higher biomass production (Sarlikioti et al., 2011). However, increasing internode length in seedlings can be detrimental as reported in tomato with longer internodes originating adult plants with later production of flower buds (Glowacka, 2004). 


\section{Cucumber root length}

Length of cucumber root differed between all-time interval periods, with an exception only at 8 DAT $(F=1.75, P=0.18)$ (Fig. 2d). The cubic polynomial regression model had the best fit in this case (Fig. $3 \mathrm{~d}$ ). The longer cucumber roots were observed in $62 \mathrm{~mm}$ irrigation levels at most of the time intervals. The lowest root length was $186 \mathrm{~mm}$ (Fig. 3d). Root length regression equations and coefficients were $62 \mathrm{~mm}(\mathrm{y}=$ $0.81+0.12 x+0.22 x^{2}-0.17 x^{3}$ and $\left.R^{2}=0.98\right), 93 \mathrm{~mm}(y=0.16-$ $0.13 x+0.66 x^{2}-0.56 x^{3}$ and $\left.R^{2}=0.99\right), 124 \mathrm{~mm}(y=0.14-$ $0.13 x+0.82 x^{2}-0.82 x^{3}$ and $\left.R^{2}=0.97\right), 155 \mathrm{~mm}(y=0.14-$ $0.12 x+0,67 x^{2}-0.64 x^{3}$ and $\left.R^{2}=0.98\right)$ and $186 m(y=0.16-$ $0.14 x+0.61 x^{2}-0.51 x^{3}$ and $\left.R^{2}=0.96\right)$.

The higher root length at $124 \mathrm{~mm}$ irrigation level, mainly from the $29 \mathrm{DAT}$, indicates better water availability for plant and a maximum nutrient absorption capacity. Longer root lengths up to 22 DAT in plants with only $62 \mathrm{~mm}$ are due to the elongation of the root tissues searching for water in deeper layers. However, water stress limits cell division ceasing plant growth, and consequently, increasing the root zone of cucumber (Mundalia et al., 2015). Water excess did not necessarily indicate a favorable environment for cucumber root growth, since it was higher at $186 \mathrm{~mm}$ irrigation level. A better cucumber root development subjected to water stress has also been reported (Franco et al., 2011). Nutrient leaching, a common problem in drip irrigation, may have reduced nutrient availability for cucumber root development (Blanco and Folegatti, 2002).

\section{Cucumber yield}

The pickling cucumber yield varied at irrigation levels following a quadratic polynomial regression model (Fig. 4a). The highest cucumber yield was observed at $124 \mathrm{~mm}(2,205$ $\mathrm{kg} \mathrm{plant}^{-1}$ ), while the lowest at $62 \mathrm{~mm}\left(1,248 \mathrm{~kg} \mathrm{plant}^{-1}\right)$ (Fig. 4a). Intermediate yields, with values of 1,562, 1,600 and $1,690 \mathrm{~kg} \mathrm{plant}^{-1}$ were observed in $93 \mathrm{~mm}, 155 \mathrm{~mm}$ and 186 $\mathrm{mm}$ irrigation levels, respectively (Fig. 4a). Yield regression equation and coefficient were $y=-0.40+0.42 x-0.18 x^{2}$ and $R^{2}=0.69$. Cucumber plants began to produce fruits from the $36^{\text {th }}$ DAT, independent of the irrigation levels (Fig. $4 \mathrm{~b}$ to $\mathrm{f}$ ). Plants submitted to $124 \mathrm{~mm}$ were the only ones to maintain high yield values in all five crops evaluated (Fig. 4d). Irrigation levels of $62 \mathrm{~mm}$ and $93 \mathrm{~mm}$ provided cucumber plants with medium yields throughout the evaluated harvest days (Fig. $4 \mathrm{~b}$ and $\mathrm{c}$, respectively). High yield values were observed only at 64 DAT for irrigation levels of 155 (Fig. 4e) and $186 \mathrm{~mm}$ (Fig. 4f), while at the other time intervals, medium yields were achieved.

The variation of pickling cucumber yield in irrigation levels followed a quadratic polynomial regression model, evidencing a strong relationship between increased water availability and cucumber yield (Yuan et al. 2006; Oliveira et al. 2011). This may be associated to water excess and nutrient leaching out of the plant root zone. Water excess may also limit oxygen flow between soil pores, impairing root respiration (Whitmore and Whalley 2009). The lower pickling cucumber yield, with $62 \mathrm{~mm}$ and $93 \mathrm{~mm}$, characterizes a water stress condition showing the need of irrigation management to balance the physiological plant demands and preventing water losses, a scarce environmental resource in many parts of the world, including use of resistance elicitors in cucumber plants against stress (Ouzounidou et al., 2016).

\section{Materials and Methods}

\section{Experimental site}

The experiment was conducted from September to December 2016, at the Horta Field Lab (South latitude 17이'10", West longitude 4812'38" and altitude of $697 \mathrm{~m}$ ), Federal Institute Goiano, Urutaí campus, state of Goiás, Brazil. The climate of the region, according to the classification of Köppen, is tropical with dry winter and rainy summer, type Cwb. Cucumber plants were cultivated in agricultural greenhouse, simple arc type, with East-West orientation and made by metallic structure $(30 \mathrm{~m}$ long, $7 \mathrm{~m}$ width and $6.2 \mathrm{~m}$ arc height) covered with low-density polyethylene (LDPE) film ( $0.15 \mathrm{~mm}$ thick) and its sides with anti-aphid mesh.

The soil of the experimental area was classified as dystrophic Yellow Red Latosol, sandy loam soil, with the following characteristics: Organic matter $=24 \mathrm{~g} \mathrm{dm}^{-3} ; \mathrm{pH}\left(\mathrm{CaCl}_{2}\right)=6.0$; $P_{\text {resin }}=300 \mathrm{mg} \mathrm{dm}^{-3}, \mathrm{~K}^{+}=4.98, \mathrm{Ca}^{2+}=57, \mathrm{Mg}^{+2}=22, \mathrm{H}+\mathrm{Al}=104$, CTC $=104 \mathrm{Cmol}_{\mathrm{c}} \mathrm{dm}^{-3}$, and Total sand $=275$, Clay $=160$, Silt $=241 \mathrm{~g} \mathrm{~kg}^{-1}$ with $80 \%$ of saturation bases (at $0-20 \mathrm{~cm}$ depth) and organic matter $=16 \mathrm{~g} \mathrm{dm}^{-3} ; \mathrm{pH}\left(\mathrm{CaCl}_{2}\right)=5.7 ; \mathrm{P}_{\text {resin }}=280$ $\mathrm{mg} \mathrm{dm}{ }^{-3}, \mathrm{~K}^{+}=4.34, \mathrm{Ca}^{2+}=55, \mathrm{Mg}^{+2}=14, \mathrm{H}+\mathrm{Al}=20, \mathrm{CTC}=93$ $\mathrm{Cmol}_{\mathrm{c}} \mathrm{dm}^{-3}$, and Total sand $=329$, Clay $=186$, Silt $=202 \mathrm{~g} \mathrm{~kg}^{-1}$ with $78 \%$ of saturation bases (at $21-40 \mathrm{~cm}$ depth).

\section{Experimental design and treatments}

The experimental design was randomized blocks with five treatments represented by five irrigation levels (amounts of applied water of 62, 93, 124, 155 and $186 \mathrm{~mm}$ ) and four replications. A 12-plant plot spaced $0.20 \mathrm{~m}$ between plants and $0.80 \mathrm{~m}$ between planting lines represented an experimental unit.

\section{Irrigation management}

Cucumber plants were irrigated with $124 \mathrm{~mm}$, and $100 \%$ of water replacement to increase soil moisture to field capacity, considering mean depth values of cucumber root system as $0.30 \mathrm{~m}$. The maximum crop evapotranspiration was estimated by the expression Etc $=(\mathrm{Eto})(\mathrm{Kc})$; where ETo was the reference evapotranspiration and $\mathrm{Kc}$ the crop coefficient. A drip irrigation system was used in each plant line receiving an irrigation lateral line (auto-compensated driplines) of $18 \mathrm{~mm}$ diameter, with emitters spaced $0.3 \mathrm{~m}$. The irrigation system had a $1 \mathrm{HP}$ motor pump. A Venturi type fertilizer injector, plus a 120-mesch screen filter, valves and pressure gauges besides the irrigation system were installed shortly after pumping water. Polyethylene liners were buried longitudinally between the beds at $0.50 \mathrm{~m}$ depth to avoid interference between the irrigation treatments.

\section{Plant material and management}

Cucumber Amour F1 hybrid (Bejo Sementes do Brasil Ltda., Bragança Paulista, São Paulo, Brazil) was used as plant material. The seedlings were sowed in styrofoam 162 cells 
trays. Transplantation of seedling was carried about 12 days after sowing, leaving one seedling per pit. The irrigation management according to the treatments started at 20 days after transplanting (DAT), a period necessary for the standardization and verification of cucumber seedling viability. Unviable seedlings were replaced by healthy ones from the stock, and with the same age up to 20 DAT. Fertilizers with macro and micronutrients were applied by drip irrigation according to soil chemical analysis and Trani et al. (2011) recommendations. Weeds were controlled by manual weeding and pests and diseases with periodic pesticide spraying. Chemical products applied during the experiment based on the manufacturer package, with the use of Personal Protective Equipment (PPE) according to Brazilian legislation.

The cucumber plants, from 18 DAT, were tutored by chains with a base support for eight strands of plain wire fixed on wood piles up to $3.0 \mathrm{~m}$ height. Fruits, flowers, leaves and lateral stems were removed to a height of $20 \mathrm{~cm}$ from the plant base, when they reached about $50 \mathrm{~cm}$. Pruning was repeated until plants reached about $1.0 \mathrm{~m}$, eliminating all structures up to $30.0 \mathrm{~cm}$. This cultural management is important to maintain high productive rates of cucumber plants (Nomura and Cardoso 2000) and followed technical recommendations from Conservas Oderich SA (an industry that processes and markets pickled cucumbers and where the idea of this study came from).

\section{Traits measured}

Temperature and relative humidity, inside the greenhouse, were monitored daily with a digital thermohygrometer (Incoterm ${ }^{\circledast}$, model 7666) installed in a meteorological shelter at the center of the greenhouse at $1.5 \mathrm{~m}$ height. The minimum, mean and maximum temperature and relative humidity were recorded, daily. Cucumber plant height, stem diameter, internode length and root length were quantified under nine intervals $(8,15,22,29,36,43,50,57$ and 64 days after transplanting, DAT). Commercial fruits (absence of cracks or bent) and length (between 6 and $8 \mathrm{~cm}$ ) began to be harvested at 39 DAT, with intervals of two days, depending on the time needed to reach the harvesting point. Fruits per plant were counted and weighed to estimate the yield values. The average cucumber yield was based on the number of fruits and fruit mass per plant per irrigation level. Yield was demonstrated in mass per plant $\left(\mathrm{kg}\right.$ plant $\left.^{-1}\right)$. Plant yield as a function of the nine-time intervals after transplanting $(8,15,22,29,36,43,50,57$ and 64 DAT) was also quantified.

\section{Statistical analysis}

All data had their normality verified by the Lilliefors adherence test and also by the proportion of the histogram obtained by the SAEG ${ }^{\circ}$ software (UFV, Viçosa, MG, Brazil). All variables quantified followed normal distribution, and consequently, their values and means were presented without transformation. Data used for regression analyzes were plotted in a dispersion diagram to verify the growth and yield variables of the cucumber plants as a function of the evaluation days, per treatment. After this procedure, ANOVA for regressions were performed and compared to obtain the best fit regression model. The regression coefficient (adjusted $R^{2}$ ) and the $F$ test values and significance were used to verify if the proposed model was adequate to describe the responses. Coefficients were described in the figures, individually, per regression analysis. Statistical analyzes (ANOVA and regression analysis models) were obtained using SAEG ${ }^{\circ}$ software, and figures were performed by SigmaPlot software, version 11 (Systat Software Inc, San Jose, California, EUA).

\section{Conclusions}

Plant height and internode length responses were not as influenced by the irrigation levels as stem diameter and root length. This indicates that in pickling cucumber, stem diameter and root length may be easy-to-check indicators for farmers to predict plant adaptation for a given irrigation management. Cucumber yield was low at $62 \mathrm{~mm}$ and 93 $\mathrm{mm}$, while higher in $124 \mathrm{~mm}$ irrigation, and delayed at 155 $\mathrm{mm}$ and $186 \mathrm{~mm}$. The benefits of using $124 \mathrm{~mm}$ irrigation level $(100 \%$ of water replacement to increase soil moisture to field capacity) for the cucumber development and yield, may reduce excessive spending of water in agriculture as well mitigate negative impacts of water deficit to Cucumis sativus plants.

\section{Acknowledgements}

Thanks to IF Goiano, Urutaí campus where the experiment was carried out and to CNPq and FAPEG for financial support and also all students who assisted in the field experimental procedures.

\section{References}

Ando K, Grumet R (2006) Evaluation of altered plant architecture as a means to reduce Phytophthora capsica disease incidence on cucumber fruit. J Amer Soc Hort Sci. 131:491-498.

Anjum SA, Xie XY, Wang LC, Saleem MF, Man C, Lei W (2011) Morphological, physiological and biochemical responses of plants to drought stress. Afr J Agric Res. 6:2026-2032.

Blanco FF, Folegatti MD, Nogueira MCS (2002) Fertirrigação com água salina e seus efeitos na produção do pepino enxerta do cultiva do em ambiente protegido. Hortic Bras. 20:442-446.

Blanco FF, Folegatti MV (2001) Recuperação de um solo salinizado após cultivo em ambiente protegido. Rev Bras. Eng Agríc Ambient. 5:76-80.

Blanco FF, Folegatti MV (2002) Manejo da água e nutrientes para o pepino em ambiente protegido sob fertirrigação. Rev Bras Eng Agríc Ambient. 6:251-255.

Canizares KAL, Goto R (2002) Comparação de métodos de enxertia em pepino. Hortic Bras. 20:95-99.

Espínola HNR, Andriolo JL, Bartz HR (2001) Acúmulo e repartição da matéria seca da planta de pepino tipo conserva sob três doses de nutrientes minerais. Cienc Rural. 31:387-392.

Franco JA, Bañón S, Vicente MJ, Miralles J, Martínez-Sánchez JJ (2011) Root development in horticultural plants grown under abiotic stress conditions - A review. J Hortic Sci Biotec. 86:543-556. 
Glowacka B (2004) The effect of blue light on the height and habit of the tomato (Lycopersicon esculentum Mill.) transplant. Folia Hortic. 16:3-10.

Jaffar A, Wahid F (2014) Effect of row spacing on growth, yield and yield components of cucumber varieties. Sci Lett. 2:33-38

Kahlen K, Chen TW (2015) Predicting plant performance under simultaneously changing environmental conditions The interplay between temperature, light, and internode growth. Front Plant Sci. 6:1130.

Klink CA, Machado RBA (2005) A conservação do Cerrado brasileiro. Megadiversidade. 1:147-156.

Mundalia L, Joshi U, Rampuria S, Meghwal R, Kumar S, Sharma R (2015) Effect of water stress on growth and antioxidative defense system in Cucumis spp. at seedling stage. Indian J Agric Sci. 85:628-633.

Nomura ES, Cardoso All (2000) Redução da área foliar e o rendimento do pepino japonês. Sci Agric. 57:257-261.

Oliveira EC, Carvalho JA, Silva WG, Rezende FC, Gomes LAA, Jesus MCN (2011) Análise produtiva e econômica do pepino japonês submetido a diferentes lâminas de irrigação. Rev Bras Eng Agríc Ambient. 15:702-708.

Ouzounidou G, Giannakoula A, Ilias I, Zamanidis P (2016) Alleviation of drought and salinity stresses on growth, physiology, biochemistry and quality of two Cucumis sativus L. cultivars by Si application. Braz J Bot. 39:531-539.
Randall HC, Locascio SJ (1988) Root growth and water status of trickle-irrigated cucumber and tomato. J Am Soc Hortic Sci. 113:830-835.

Reis NVB, Horino Y, Oliveira CAS, Boiteux LS (1991) Influência da radiação fotossinteticamente ativa (RFA) sobre os componentes de produção de nove genótipos de pepino plantado a céu aberto e sob estufas plásticas. Hortic Bras. 9:55.

Sarlikioti V, Visser PHB, Marcelis LFM (2011) Exploring the spatial distribution of light interception and photosynthesis of canopies by means of a functionalstructural plant model. Ann Bot. 107:875-883.

Sibomana IC, Aguyoh JN, Opi AM (2013) Water stress affects growth and yield of container grown tomato (Lycopersicon esculentum Mill) plants. Global J Biosci Biotechnol. 2:461466.

Trani PE, Tiveli SW, Carrijo OA (2011) Fertirrigação em hortaliças. 2.ed. Campinas: Instituto Agronômico, Série Tecnologia APTA. Boletim Técnico IAC. 196. 51 p.

Whitmore AP, Whalley WR (2009) Physical effects of soil drying on roots and crop growth. J Exp Bot. 60:2845-2857.

Yaghi T, Arslan A, Naoum F (2013) Cucumber (Cucumis sativus, L.) water use efficiency (WUE) under plastic mulch and drip irrigation. Agric Water Manag. 128:149-157.

Yuan BZ, Sun J, Kang Y, Nishiyama S (2006) Response of cucumber to drip irrigation water under a rain shelter. Agric Water Manag. 81:145-158. 